GORDAN STOJIĆ, Ph.D.

E-mail: gordan@uns.ac.rs

University of Novi Sad, Faculty of Technical Sciences

Trg Dositeja Obradovića 6, 21000 Novi Sad, Serbia

SLAVKO VESKOVIĆ, Ph.D.

E-mail: veskos@sf.bg.ac.rs

University of Belgrade, Faculty for Traffic and Transportation

Vojvode Stepe 305, 11000 Belgrade, Serbia

ILIJA TANACKOV, Ph.D.

E-mail: ilijat@uns.ac.rs

University of Novi Sad, Faculty of Technical Sciences

Trg Dositeja Obradovića 6, 21000 Novi Sad, Serbia

SANJIN MILINKOVIĆ, M.Sc.

E-mail: sanjin@sf.bg.ac.rs

University of Belgrade, Faculty for Traffic and Transportation

Vojvode Stepe 305, 11000 Belgrade, Serbia
Transport Management Preliminary Communication Accepted: Nov. 11, 2010 Approved: Mar. 14, 2012

\title{
MODEL FOR RAILWAY INFRASTRUCTURE MANAGEMENT ORGANIZATION
}

\section{ABSTRACT}

The provision of appropriate quality rail services has an important role in terms of railway infrastructure: quality of infrastructure maintenance, regulation of railway traffic, line capacity, speed, safety, train station organization, the allowable lines load and other infrastructure parameters.

The analysis of experiences in transforming the railway systems points to the conclusion that there is no unique solution in terms of choice for institutional rail infrastructure management modes, although more than nineteen years have passed from the beginning of the implementation of the Directive 91/440/EEC. Depending on the approach to the process of restructuring the national railway company, adopted regulations and caution in its implementation, the existence or absence of a clearly defined transport strategy, the willingness to liberalize the transport market, there are several different ways for institutional management of railway infrastructure.

A hybrid model for selection of modes of institutional rail infrastructure management was developed based on the theory of artificial intelligence, theory of fuzzy sets and theory of multicriteria optimization.

\section{KEY WORDS}

management, railway infrastructure, organizational structure, hybrid model

\section{INTRODUCTION}

Most countries of the European Union, countries aspiring for EU membership, and other countries in the world, have accepted the directives relating to the restructuring of the railway system. Until now, the railway restructuring did not allow: full liberalization of rail transport market, an expected positive performance of the railway system, satisfying the transport market demands, required level of rail service quality, meeting the interests of the community at the national, regional and local levels, etc. The restructuring of railway system, mainly brought partial positive operating results in the main railway routes, or Pan-European corridors, especially in transit transport. Although the quality of railway system slightly increased, it is still far from the level that transportation market requires. Rail infrastructure has an important role in providing appropriate quality of rail services.

The definition of the national railway companies restructuring and the modes for infrastructure management in Europe are mainly based on expert opinions, and depend on the defined traffic policies, country development, as well as on the willingness for accepting the changes (political, social and other reasons).

The analytical review of the future railways development in the new circumstances of the transport market, the liberalization of the railways and the privatization of railways as providers of services is given in paper [1]. Paper [2] presents a new model of railway traffic management as the basis for efficient activity and harmonization of railway traffic management in the Republic of Slovenia to the systems of railway traffic management within EU.

There are numerous examples for the application of Multiple Criteria Optimization (MCO) in traffic and transport. A wide range of application of MCO meth- 
ods can be seen in the models for optimal pedestrian crossing [3], measuring of the passengers service quality [4], the prioritization of the investments in transport infrastructure [5], and model for creating a design and construction of railway infrastructure on Pan-European Corridors $\mathrm{V}$ and $\mathrm{X}$ by macroeconomic and infrastructure criteria for MCO [6]. The limitation of this approach is greater subjectivity in definition and quantification of the criteria.

The simulation model which allows an infrastructure manager to control the railway infrastructure and optimize track availability by taking into account the size of the limited speed sections and track closures can be seen in paper [7].

Recently, the use of artificial intelligence and hybrid models in traffic and transport has increased. An overview of such models is presented in paper [8].

We present a hybrid model based on the theory of artificial intelligence (Case-based reasoning (CBR) methodology), the theory of fuzzy sets and the theory of MCO. Based on the hybrid model, the developed software named UZI-CBR ${ }^{1}$ acts as an expert decision system for selection of the method (model) for the railway infrastructure institutional management.

\section{UZI-CBR HYBRID MODEL}

CBR is used for solving problems in domains where experience plays an important role. Generally speaking, CBR aims to solve new problems by adapting solutions that were successfully applied to similar problems in the past. The main supposition here is that the problems that are similar have similar solutions.

The application of CBR methodology in traffic and activities related to traffic is important. ICARUS is a known fault-diagnosis system for locomotives [9], a system for interactive computer-aided aircraft design [10], CBR systems for conceptual design of auxiliary ships [11], and others.

The CBR methodology can successfully offer a solution for new problems (cases) based on the results of similar problems in the previous experience. A similar problem is the choice of institutional management for railway infrastructure. On one hand there is the base for different experiences of restructuring the railway system solutions to the selected sample countries, and on the other hand any rail system and its infrastructure can be observed and a solution can be found based on experience.

The algorithm for the hybrid model is shown in Figure 1.

Based on the experiences related to the way of managing the railway infrastructure, this model consists of the following countries: the United Kingdom, France, Germany, the Netherlands, Estonia, Italy, Austria, Poland, the Czech Republic, Slovak Republic,

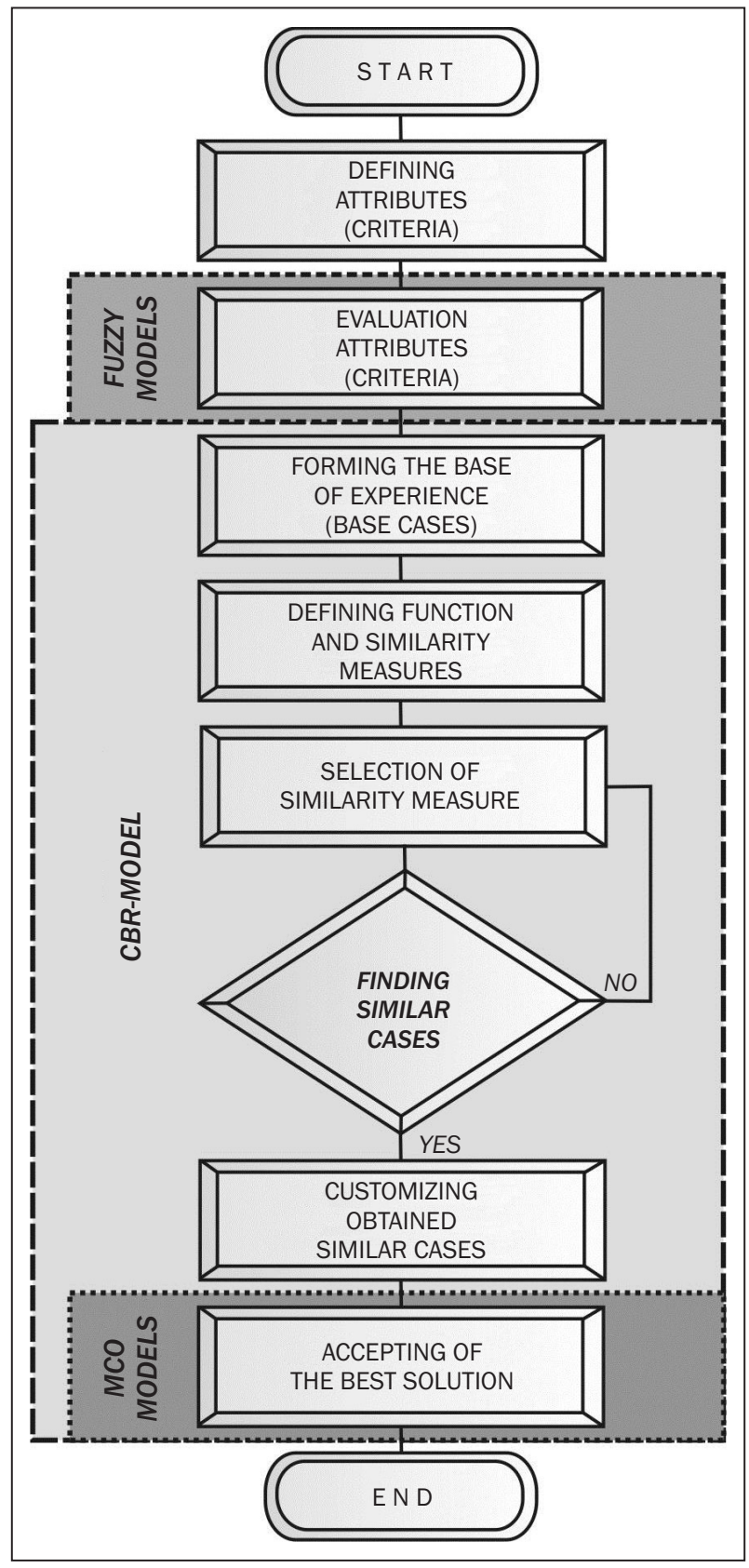

Figure 1 - Algorithm for obtaining solutions in the hybrid model UZI-CBR

Hungary, Romania, Bulgaria, Slovenia, Croatia, Albania, Bosnia and Herzegovina, Macedonia $(N=18)$. The CBR methodology includes well-known phases as shown in Figure 2.

The most important and also the most difficult moment in the implementation of CBR methodology is finding the appropriate measure of similarity. The similarity can be defined as a function of:

sim: $U \times C B \rightarrow[0,1]$

where:

$U$ - the set of all objects in the system;

$C B$ - Case Base (only those cases that were resolved and recorded in the past). 


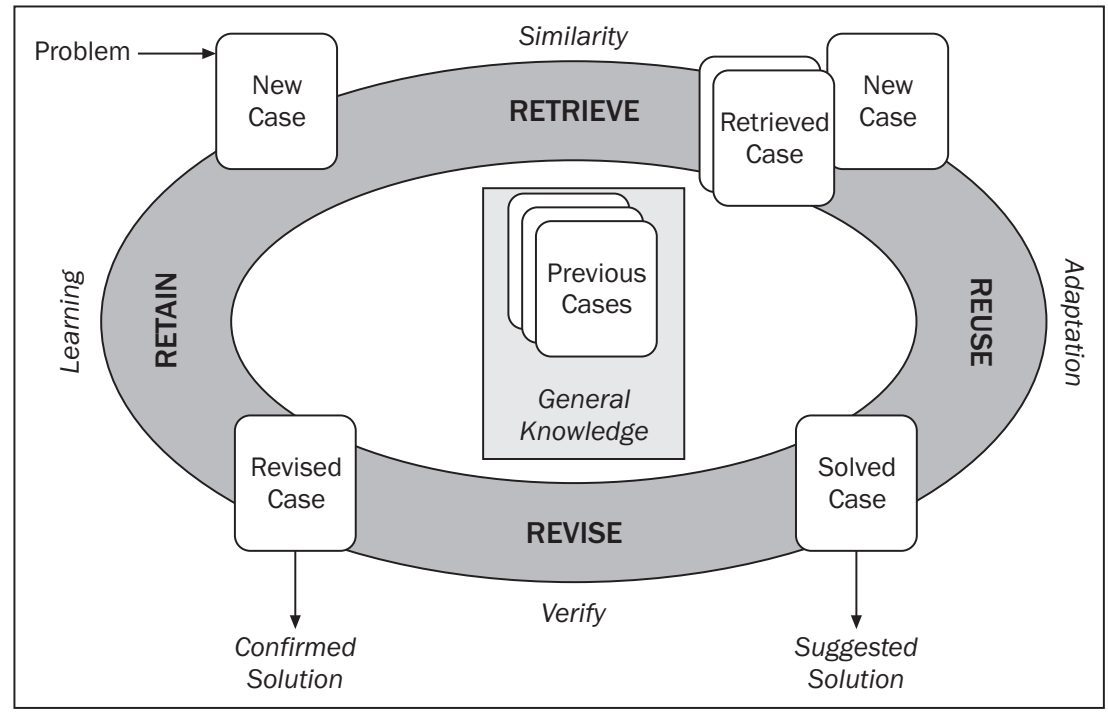

Figure 2 - Main phases of the CBR methodology

Higher value of the function similarity ( $\mathrm{sim}$ ) shows that two objects are more similar. Limiting case of $\operatorname{sim}(x, x)=1$, which means that the object is most similar to itself.

Different measures of similarity are established: the superficial similarity (differing only syntactic properties of representations), the local similarity (considering only the similarity of some attributes) and global similarity (a complete view of the case).

For each new case of institutional management of railway infrastructure, in the phase "RETRIEVE" the most similar problems are identified on the base of experience and their successful solution. We defined global similarity, which is used for searching the base of cases by using the function:

$$
F_{n}\left(P S, S S_{n}\right)=\sum_{i=1}^{k} \sum_{j=1}^{l} f\left(P S, S S_{n_{i j}}\right) w_{i} ; n=1,2, \ldots N
$$

where:

$F_{n}$ - similarity between the observed (actual) cases (PS) and the $n$-th stored case $\mathrm{SS}_{n}$;

$k$ - finite number of defined attributes (sets of criteria);

I - finite number of defined observed attributes values (sets of criteria);

$N$ - total number of stored cases:

$f$ - function of similarity of the observed cases $(P S)$, according to the $i$-th attribute and its $j$-th value of $n$-th stored case $\left(S_{n_{i j}}\right)$;

$w_{i}$ - importance (weight) of the $i$-th individual attributes; the range of the attribute is $[0,1]$ where attributes with higher significance have a higher weight. More significant attributes have weight $w=1$, and less significant attributes have weight $w=0.5$.

Sets of criteria are established on the basis of the attributes in the phase "RETRIEVE" and their similarity.
The infrastructure has a complex position on the market. On one hand it is necessary to meet the market and transporters' demands, and on the other hand the requirements of communities at national, regional and local levels. For this reason it is very important to define a rational (optimal) ${ }^{2}$ way of managing rail infrastructure. To achieve this it is necessary to define the criteria that will determine the institutional management of railway infrastructure.

In this paper, the evaluation methods of institutional management of railway infrastructure are defined with sets of criteria for assessment:

1. size of the country (region);

2. levels of economic development;

3. infrastructure development;

4. level of reform of the railway system.

The set of criteria about the size of countries (regions) consist of the following criteria: country size, population and population density. The set about the level of economic development consists of: population, GDP, GDP per capita, and unemployment rate, and the set of infrastructure development criteria: the total length of railways, the density of the network, the percentage of electrified railways, and the percentage of double track lines and multiple track lines. The assessment of the reform level of the railway system was carried out by using the following criteria: the preparedness of countries for railway reform, new regulations (laws), improved management structure, liberalization of the railway market, open access to infrastructure for operators, commercial business enterprises, subsidies for passenger transport, adjusting the number and structure of employees and the number of railway operators.

For the evaluation of sets of criteria the theory of fuzzy sets is applied, which is a convenient tool when we need to evaluate the appearance of subjectivity, 


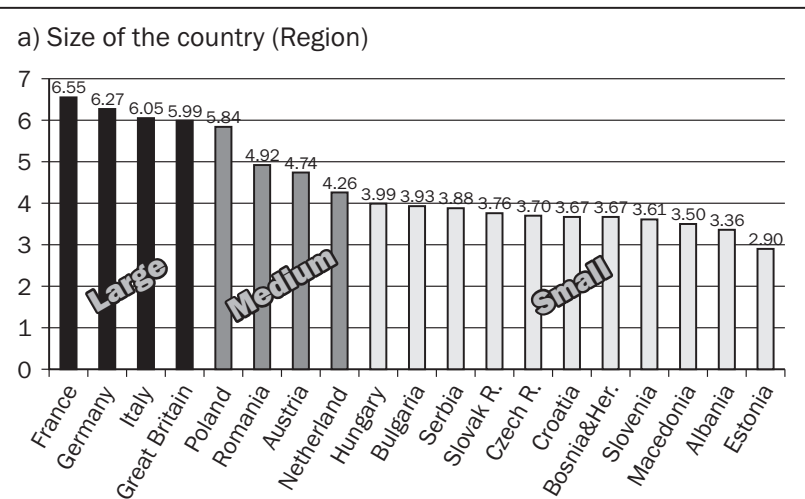

c) Development of railway infrastructure

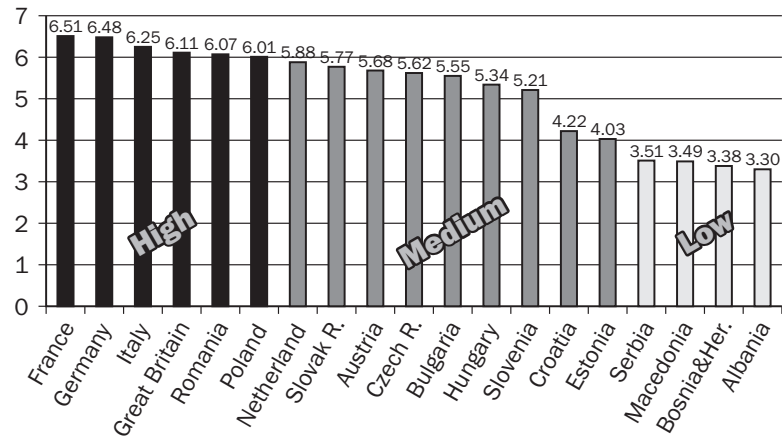

b) Level of economic development

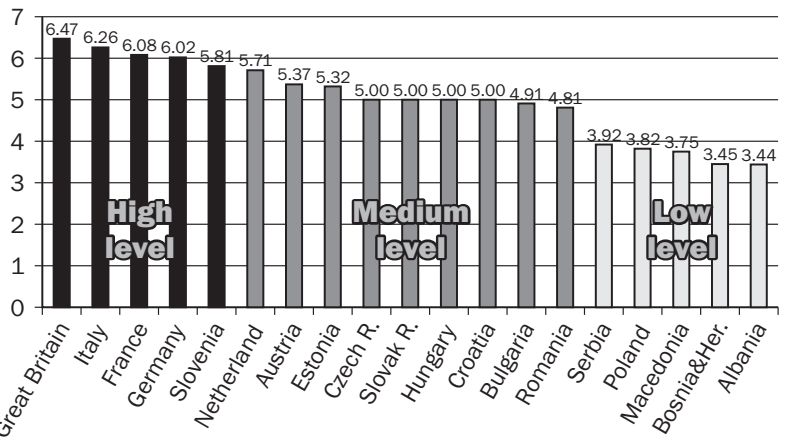

d) Level of reform of the railway system

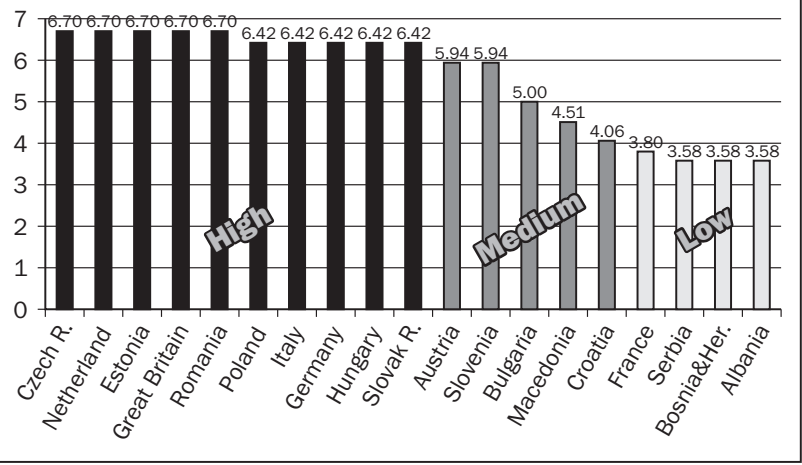

Figure 3 - Fuzzy sets evaluation criteria

imprecision, and ambiguity. The evaluation of the set of criteria about the size of countries (regions) is shown in paper [12], the development of railway infrastructure [13], and the level of reform of the railway system in [14]. In a similar way the evaluation of the level of economic development of countries was done. The results of the evaluation of the sets of criteria based on the theory of fuzzy sets are shown in Figure 3.

Considering that fuzzy sets are characterized by vagueness, the values are not crisp, but descriptive or fuzzy. Fuzzy sets are defined as values around 4 and 6 according to predefined output functions of fuzzy sets: "Size of the country (Region)", "Level of economic development", "Development of railway infrastructure" and "Level of reform of railway system".

Each attribute can have one of three values $(I=3)$ : low (weak, low level, small), medium (intermediate, middle, secondary), or high (high level, high, great).

After finding similar cases from the base, this is followed by phase "REUSE" in which specific adaptations are made. These adaptations are related to the application of theoretical model of company organization, national laws relating to railroads, businesses, companies, etc., and the conditions of territorial infrastructure distribution. The following models of organizational structure are established: a model of a single legal entity, the model of a single legal entity with its partners, a model of pure holding company, model of mixed holding and the model of independent companies. For their design a divisional model with combined structure was selected. At higher hierarchical levels there is subjective structure to the lower territorial structure.

In the phase "REVISE" in which the evidence of the accuracy and external validation is expected, in this model MCO is applied. For the purposes of MCO new (specific) criteria are defined: model efficiency, attractiveness of models to attract operators, satisfying the needs of transport market, compliance with EU directives, financial independence model, and possibility of realization of the model.

The efficiency is the ability to achieve results and business goals. This means, in relation to railway infrastructure management, the offered model should be capable of effective operation and maintenance. The criterion should be maximized.

The criterion "attractiveness of models to attract operator" means ability of the model in which operators provide open access to infrastructure, i.e. use of infrastructure by the operators on equal terms free of discrimination. The criterion should be maximized.

The criterion "meeting the needs of transport market" refers to the ability of the proposed model to meet the needs of operators in the transport market in relation to the condition and capacity of railway infrastructure capacity (maximum speed, line capacity, 


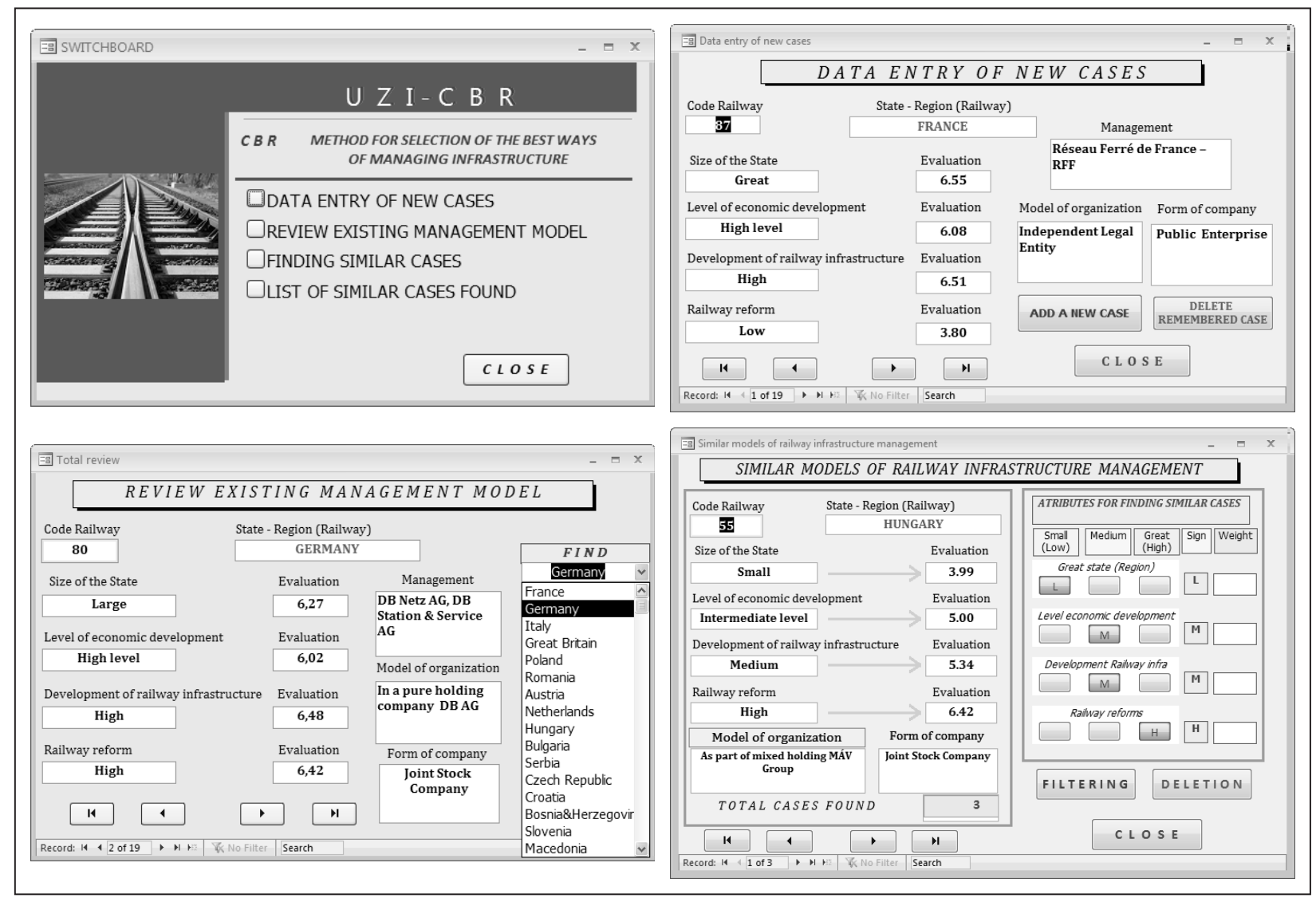

Figure 4 - Interface for UZI-CBR expert system

power supply, permissible axle load, etc.). The criterion should be maximized.

Certain models for managing railway infrastructure can be fully or to some extent harmonized with EU directives aimed at completing the single transport market, the liberalization and ensuring the independence of railway management companies. The criterion should be maximized.

The infrastructure operator should be a functionally capable and financially stable company. The country set aside funds for infrastructure operators for infrastructure development, but not for the workers' salaries. The criterion "financial independence model" should assess how the model can be offered to satisfy these requirements. The criterion should be maximized.

The criterion "possibility of realization of the model" refers to the possibility of realization of the considered model in terms of legislation, environment, support of political, social and other participants and the like. The criterion should be maximized.

In the phase "RETAIN" the accepted solution of the observed problems is stored in the database of solved cases as new successfully resolved case.

UZI-CBR expert system user windows are shown in Figure 4, and the results of model testing for the defined parameters are presented in Figure 5.

\section{TEST OF A HYBRID MODEL AND DISCUSSION}

The model was tested on a railway network that is located on the territory of Vojvodina. By applying the fuzzy quantification model evaluation criteria were obtained for the region of Vojvodina (Table 1).

The obtained fuzzy scores for AP Vojvodina, except for the estimation of the level of railway reforms, were used to find similar cases in the UZI-CBR model. Taking into account the aspirations of Serbia for EU membership and obligations that must be carried out on the road to membership, which includes the restructuring of the railway system (EU Directives), as well as already implemented reforms of railway systems in the region, the search of similar cases from the base should raise the level of railway reform. This means that when the database searching of cases is performed, the required level of railway reforms are applied, not the existing ones for the observed example: ("Low" railway reform).

The phase "RETRIEVE" in the UZI-CBR model has been implemented for advanced "gradual" and "radical" approach to restructuring the railway system. The gradual approach implies a longer transition period, while a radical process implies "fast" and "sharp" transformation of the railway company in terms of its 


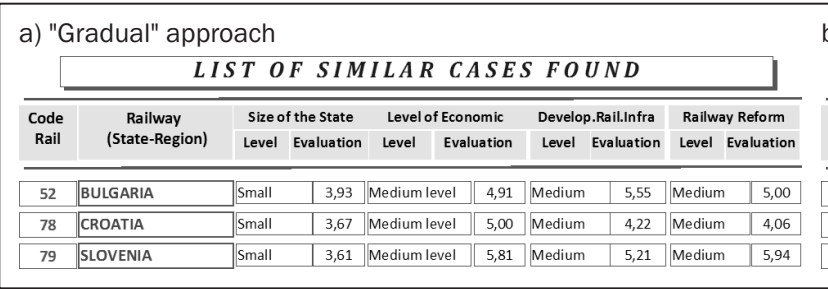

b) "Radical" approach

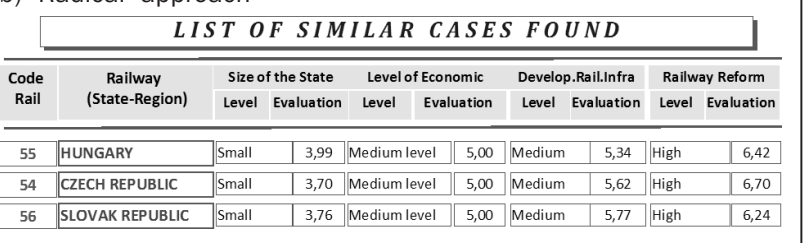

Figure 5 - List of similar cases found in the example of the railway network in AP Vojvodina

organization and relations with the country without a transition period. This means that they immediately formed at least two organizational units: infrastructure and transport.

Table 1 - Quantification of sets of criteria for the example of AP Vojvodina

\begin{tabular}{|l|c|c||}
\hline \multicolumn{1}{|c|}{ Sets of criteria (attributes) } & \multicolumn{2}{c|}{ Ratings } \\
\hline \hline Size of region & 3.75 & SMALL \\
\hline Level of Economic Development & 4.20 & MEDIUM LEVEL \\
\hline Rail Infrastructure Development & 4.37 & MEDIUM \\
\hline Railway Reform & 3.58 & LOW \\
\hline
\end{tabular}

Rating "Medium" of the railway reform fits the gradual approach and the radical one, "High" railway reform. An equal weight (importance) is assigned to each attribute $\left(w_{i}=1\right)$. The test results are shown in Figure 5.

The results of model testing for both cases ("gradual" and "radical") are not significantly different. Advanced "gradual" approach leads to the following organizational models: single model (independent) legal entity which only operates part of the railway infrastructure which is in AP Vojvodina and the model of pure holding company that will manage with a part of infrastructure and will perform rail transport. The "Radical" approach leads to the model of a single (independent) entity and the model of a mixed holding. In general, the model was obtained by a single legal entity and holding company model with its variants: pure and mixed holding. Therefore, in this work the best model of the organization selection is made by the following three options (alternatives): a unique model (independent) legal entity (alternative $a_{1}$ ), a model of pure holding company (alternative $\mathrm{a}_{2}$ ) and a holding mixed model (alternatives a3).

The phase "REUSE" carries out adaptations of the founded similar models based on the application of theoretical models of organizational structure - division model which has a combined structure.

In the phase "REVISE" MCO was conducted. A group of experts (decision makers) is formed, consisting of experts such as: academics, relevant ministries from the country and the region, the Secretariat of the Government of AP Vojvodina, the organization SEETO, PE "Serbian Railways" and the railway infrastructure managing companies as an independent company or as a holding. The survey was conducted by the Delphi method rules.

Two MCO methods were selected (ELECTRE and PROMETHEE II) for the selection of railway infrastructure management model, and the optimal solution could not be susceptible to the use of only one method.

The results obtained by MCO ELECTRE and PROMETHEE methods are almost identical, indicating the stability of the solution. Both methods indicate that the alternative $a_{2}$ (model of a pure holding company) dominates the alternatives аз (the model of a mixed holding company) and $\mathrm{a}_{1}$ (model of a single company). This means that the most rational solution for the institutional management of railway infrastructure on the territory of AP Vojvodina, is the model of pure holding company. This kind of model was applied on the Slovenian and Croatian Railways (Slovenian Railways Ltd. and HZ Holding Ltd.). The pure holding company model has been adapted and is in line with the theoretical principles model for company organization, the national laws relating to railroads, companies, as on the territorial infrastructure distribution conditions.

The organizational chart, general and detailed, the most rational model of the converted railway infrastructure management, gained in the phase of " $R E$ VISE" is shown in Figures 6 and 7.

Infrastructure operator is equal company within the holding, and the carrying out of activities should be separate. The company form should be a company with limited liability (Ltd.). The majority share of the company should not be privatized.

Infrastructure manager, basically, there should have three levels of hierarchical organizational structure (three vertical levels of management). The next level is basically the underlying form of organizational structure with three horizontal levels of management (Figure 7).

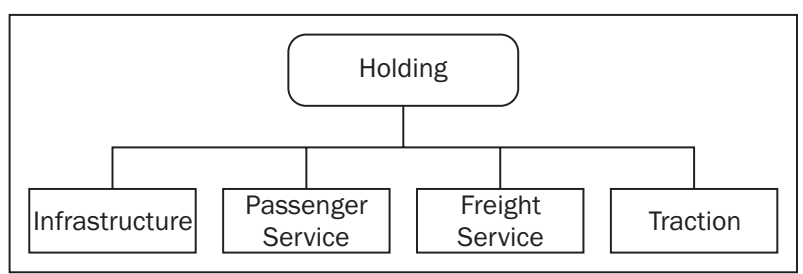

Figure 6 - The selected model of railway infrastructure management in the pure holding company (general scheme) 


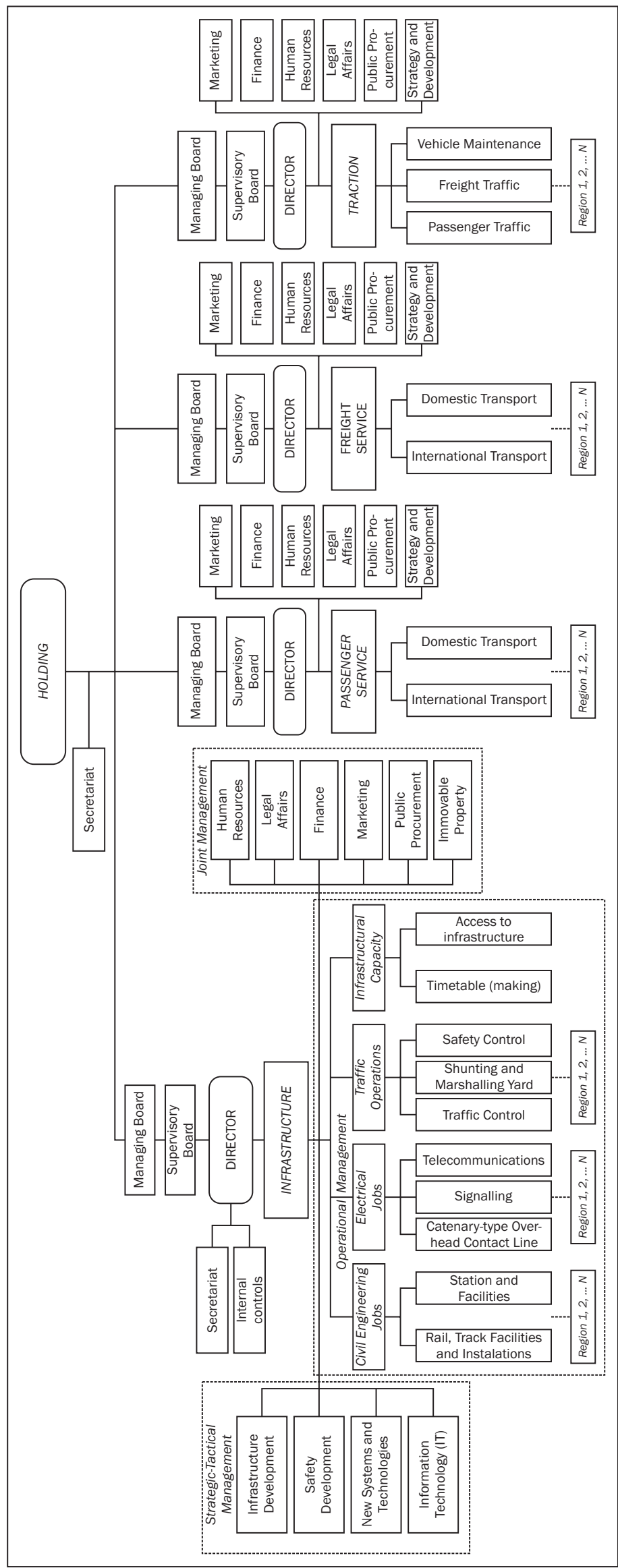

Figure 7 - The selected railway infrastructure management model as pure holding company (detailed scheme) 
As the railway infrastructure extends to a number of regions, for more equitable allocation and efficient performance, a territorial (regional) organization of infrastructure maintenance is necessary, as well as shunting operations and regulation of traffic (if the regulation is not centralized). The regions should not be defined by administrative boundaries or the like, but only by the network density, the importance of railways and equal operations division.

In the phase "RETAIN" the accepted solution to the railway infrastructure management model is stored in the database of solved cases as a new successfully resolved case.

\section{CONCLUSION}

Since the EU directives, the introduction in theory and practice, a unique solution in terms of choice of model railway infrastructure management has not been given. In practice, there are different ways of implementing the restructuring of railway systems and their adjustment to EU directives and in some systems a large lagging behind is evident (e.g. Albanian Railways, Serbian Railways, etc.).

The issue that this paper deals with is developing a general model that provides a solution about the institutional management of the railway infrastructure. For the choice of the railway infrastructure management model it is necessary to define the criteria on which the selection will be made. For that purpose, a hybrid model that provides a solution of the above mentioned problem was developed. In the paper relevant criteria for that choice are identified and quantified. The verification of the developed model was carried out on a selected example.

It is necessary to continue the research in the field of studying the behaviour of the defined criteria, and possible identification of new criteria that can influence the redefinition of the developed models of quantification and valuation in this paper or create entirely new models. Also, to explore other methods of criteria quantification using other techniques which are successfully treating various types of uncertainty and imprecision and other models for the selection assessment of the institutional management of railway infrastructure to be developed in order to compare the results. It is necessary to examine the possibility of generalization of the model in terms of its application to other transportation infrastructure.

\section{Acknowledgement}

This work is a part of the research project TR 36012 funded by the Ministry of Science and Technology of Serbia.

\section{Dr GORDAN STOJIĆ}

E-mail: gordan@uns.ac.rs

Univerzitet u Novom Sadu, Fakultet tehničkih nauka

Trg Dositeja Obradovića 6, 21000 Novi Sad, Srbija

Dr SLAVKO VESKOVIĆ

E-mail: veskos@sf.bg.ac.rs

Univerzitet u Beogradu, Saobraćajni fakultet

Vojvode Stepe 305, 11000 Beograd, Srbija

Dr ILIJA TANACKOV

E-mail: ilijat@uns.ac.rs

Univerzitet u Novom Sadu, Fakultet tehničkih nauka

Trg Dositeja Obradovića 6, 21000 Novi Sad, Srbija

Mr SANJIN MILINKOVIĆ

E-mail: sanjin@sf.bg.ac.rs

Univerzitet u Beogradu, Saobraćajni fakultet

Vojvode Stepe 305, 11000 Beograd, Srbija

\section{ABSTRAKT \\ MODEL ORGANIZACIJE UPRAVLJANJA ŽELEZNIČKOM INFRASTRUKTUROM}

U pružanju odgovarajućeg kvaliteta železničkih usluga veoma važnu ulogu ima železnička infrastruktura sa aspekta: kvaliteta održavanja infrastrukture, regulisanja železničkog saobraćaja, propusne moći pruga, brzine odvijanja saobraćaja, bezbednosti, organizacije rada u železničkim stanicama, dozvoljenog opterećenja pruge i drugih parametara železničke infrastrukture.

Analiza iskustava transformacije pojedinih železničkih sistema ukazuje na zaključak da nije dato jedinstveno rešenje u pogledu izbora načina institucionalnog upravljanja železničkom infrastrukturom iako je od početka primene direktive 91/440/EEC prošlo više od devetnaest godina. U zavisnosti od pristupa u procesu restrukturiranja nacionalnih železničkih preduzeća, donesene regulative i opreznosti $u$ njenom sprovođenju, postojanja ili nepostojanja jasno definisane saobraćajne strategije, spremnosti da se liberalizuje transportno tržište pojavili su se različiti načini institucionalnog upravljanja železničkom infrastrukturom.

U radu je razvijen hibridni model na bazi teorije veštačke inteligencije, teorije "fuzzy"skupova i teorije višekriterijumske optimizacije koji omogućava izbor načina institucionalnog upravljanja železničkom infrastrukturom.

\section{KLUČNE REČI}

upravljanje, železnička infrastruktura, organizaciona struktura, hibridni model

\section{REFERENCES}

1. UZI is an abbreviation of the term Railway management infrastructure (Serbian: Upravljanje Železničkom Infrastrukturom) and CBR is the basic applied methodology

2. Often, the solution cannot claim to be optimal, but rational. 


\section{LITERATURE}

[1] Blašković Zavada, J., Zavada, J., Hozjan, D.: Development of Railways in New Marketing Conditions, PROMET - Traffic\&Transportation, Vol. 19, No. 1, 2007, pp. 43-47

[2] Mlakar, D., Sever, D.: Railway Traffic Management As a Function of the New Infrastructure Manager, PROMET - Traffic\&Transportation, Vol. 19, No. 6, 2007, pp. 387 394

[3] Šimunović, Lj., Grgurević, I., Pašagić Škrinjar, J.: Selecting Optimal Pedestrian Crossing Using Multi-Criteria Decision-Making, PROMET - Traffic\&Transportation, Vol. 22, No. 2, 2010, pp. 105-116

[4] Nathanail, E.: Measuring the Quality of Service for Passengers on the Hellenic Railways, Transportation Research Part A: Policy and Practice, Vol. 42, Issue 1, 2008, pp. 48-66

[5] Tsamboulas, D. A.: A Tool for Prioritizing Multinational Transport Infrastructure Investments, Transport Policy, Vol. 14, Issue 1, 2007, pp. 11-26

[6] Hauc, A., Bastič, M., Jurše, L., Pšunder, M.: Model for Optimal Project Portfolio for the Construction of Railway Infrastructure on Corridors $V$ and $X$, PROMET Traffic\&Transportation, Vol. 22, No. 1, 2010, pp. 29-42

[7] Mlinarić, T. J., Pirnar, M.: Optimizing Track Infrastructure Availability, PROMET - Traffic\&Transportation, Vol. 21, No. 2, 2009, pp. 113-121
[8] Teodorović, D.: Swarm intelligence systems for transportation engineering: Principles and applications, Transportation Research Part C: Emerging Technologies, Vol. 16, Issue 6, 2008, pp. 651-667

[9] Varma, A.: ICARUS: Design and Deployment of a CaseBased Reasoning System for Locomotive Diagnostics, Proceedings of $3^{\text {th }}$ International Conference on CBR, ICCBR-99, Germany, Springer-Verlag, 1999, pp. 581595

[10] Leake, B D., Wilson C. D.: Combining CBR with Interactive Knowledge Acquisition, Manipulation and Reuse, Proceedings of 3th International Conference on CBR, ICCBR-99, Germany, Springer-Verlag, 1999, pp. 203217

[11] Dongkon, L., Kyung-Ho L.: An approach to case-based system for conceptual ship design assistant, Expert Systems with Applications 16, 1999, pp. 97-104

[12] Stojić, G., Tanackov, I., Vesković, S., Milinković, S., Simić, D.: Modelling Evaluation of Railway Reform Level Using Fuzzy Logic, Lecture Notes in Computer Science/Lecture Notes in Artificial Intelligence, Springer Berlin/Heidelberg, Vol. 5788, 2009, pp. 695-702

[13] Stojić, G., Ristanović, B., Tanackov, I., Vesković, S., Dimanoski, K.: Modeling Evaluation of the Size of Countries (Regions) Using Fuzzy Logic, Geographica Pannonica, Vol. 14 Issue 2, 2010, pp. 59-66

[14] Stojić, G., Vesković, S., Tanackov, I., Milinković, S.: Model za ocenu razvijenosti železničke infrastrukture, Tehnika-saobraćaj, Vol. 57, No. 4, 2010, pp. 1-7 